УДК 343.14

DOI https://doi.org/10.51989/NUL.2021.5.16

\title{
ЛІКАРСЬКА ТАЄМНИЦЯ У КРИМІНАЛЬНОМУ ПРОЦЕСІ ТА ЗАКОНОДАВСТВІ УКРАЇНИ ПРО ОХОРОНУ ЗДОРОВ'Я
}

\section{Шумило Микола Єгорович,}

доктор юридичних наук, професор, заслужений діяч науки і техніки України, член-кореспондент Національної академії правових наук України, головний науковий співробітник відділу забезпечення інтеграції академічної та університетської правової науки та розвитку юридичної освіти Київського регіонального центру Національної академії правових наук України

\section{Рудей Владислав Степанович,}

кандидат юридичних наук, старший науковий співробітник відділу дослідження проблем взаємодії держави та громадянського суспільства Київського регіонального центру Національної академії правових наук України

\section{Дунаєвська Людмила Григорівна,}

кандидат юридичних наук, доцент кафедри кримінального процесу і криміналістики Інституту права Київського національного університету імені Тараса Шевченка

У статті досліджуються наукова і нормативна модель охорони лікарської таємниці у кримінальному процесі та законодавстві України про охорону здоров'я, розкрито проблеми правового регулювання в даній сфері, вивчено досвід зарубіжних країн, розроблено науково обґрунтовані пропозиції для вдосконалення чинного законодавства України.

Обґрунтовано, що професійна лікарська таємниця - це наявність відомостей про факт звернення по медичну допомогу; даних про сам факт лікування; стан здоров'я особи; обізнаність із медичним та немедичним характером сімейного й інтимного життя хворого.

Визначено, що правовий режим охорони права особи на лікарську таємницю у кримінальному процесі України передбачає можливість його тимчасового обмеження, а в окремих випадках - абсолютну недоторканість цього права.

Розкрито підходи законодавця щодо визначення підстав для надання лікувальними закладами стороні обвинувачення відомостей, що охоплюються визначенням «лікарська таємниця».

Констатовано, що правові підстави для надання лікувальними закладами відомостей про особу, що становлять лікарську таємницю, стороні кримінального провадження є неоднаковими через відсутність єдиної і послідовної позиції законодавця.

Аргументовано, що норми, які визначають умови та порядок надання відомостей, що становлять лікарську таємницю, мають бути зрозумілими й однозначними, забезпечувати гарантії проти можливого свавілля і зловживання з боку держави.

Розроблено зміни і доповнення до чинного законодавства України, відповідно до яких єдиною правовою підставою для розкриття лікувальними закладами відомостей, що становлять лікарську таємницю, має бути ухвала слідчого судді або суду.

Запропоновано, щоб лікувально-профілактичні заклади, до яких доставлено особу внаслідок нещасного випадку, обмежувалися лише інформуванням правоохоронних органів про факт звернення по медичну допомогу без деталізації діагнозу й інших особливостей стану здоров'я. Водночас така інформація має подаватися у знеособленому вигляді, якщо пацієнт не дав добровільної згоди на розголошення даних стосовно нього.

Ключові слова: лікарська таємниця, медична таємниця, охорона лікарської таємниці, конфіденційність пацієнта, особисте життя, приватне життя. 


\section{Shumylo Mykola, Rudei Vladyslav, Dunaievska Liudmila. Medical secrecy in the criminal process and the Ukrainian health care legislation}

It is researched the scientific and normative model of medical secrecy in the criminal process and the legislation of Ukraine on health care, reveals the problems of legal regulation in this area, studies the experience of foreign countries, develops scientifically sound proposals to improve current legislation of Ukraine.

It is substantiated that professional medical secrecy is the availability of information about the seeking medical help; data about treatment; medical information about the person; awareness of the medical and non-medical nature of the patient's family and his intimate life.

It is determined that the legal regime of the protection of person's right to medical secrecy in the criminal process of Ukraine provides the possibility of its temporary restriction, and in some cases - the absolute inviolability of this right.

There are disclosed the legislator's approaches for determining the grounds for medical institutions to provide the prosecution with information covered by the concept of "medical secrecy".

It is stated that the legal grounds for medical institutions to provide information about a person constituting a medical secret to a side of criminal proceedings are not the same due to the lack of unified and consistent view of the legislator.

It is argued that the rules determining the conditions and procedure for information providing about medical secrecy should be clear and unambiguous, provide sufficient guarantees against possible arbitrariness and abuse by the state.

There are developed the amendments and additions to the current legislation of Ukraine, according to them the unified legal basis for the disclosure by medical institutions of medical secrecy information must be the decision of the investigating judge or court.

It is proposed that the treatment and prevention facilities where a person is taken because of an accident should be limited to informing law enforcement agencies about the fact of seeking medical help without detailing the diagnosis and other health conditions. In this case, such information should be provided in an impersonal form, if the patient has not given voluntary consent to the disclosure of data about him.

Key words: doctor-patient confidentiality, medical secrecy, protection of doctor-patient confidentiality, patient confidentiality, personal life, private life.

Постановка проблеми. Забезпечення недоторканності лікарської таємниці є однією з істотних умов повноцінного і комфортного існування людини в суспільстві. Дотримання конфіденційності даних про здоров'я $\epsilon$ надзвичайно важливим з погляду поваги до приватного і сімейного життя, має ключове значення як для захисту прав пацієнта, так і для збереження довіри до медичних працівників та системи охорони здоров'я загалом.

Основним призначенням інституту лікарської таємниці $€$ запобігання можливому завданню шкоди психіці пацієнта, його близьким, завданню їм моральної шкоди. Розголошення відомостей, що охоплюються лікарською таємницею, може істотно вплинути на соціальний стан та трудову зайнятість осіб, зробити їх об'єктом наруги і гонінь.

Лікарська таємниця $€$ необхідною умовою існування професії лікаря та медицини згалом. Увага до її збереження не слабшає протягом всієї історії медицини.
Відомості, які лікар отримує від хворого, містять дані про його хворобливі відчуття, фізіологічне отруєння, а також про хвороби членів сім'ї, родичів тощо. Серед них $€$ й такі, які людина за інших умов не повідомила 6 нікому. Це дані про інтимні сторони життя, фізичні та психічні вади, негаразди в побуті та на роботі, спадкові захворювання, порушення статевої функції тощо. Уся інформація, яку хворий надає лікарю, може мати велике значення в розпізнанні хвороби, а отже, у ії̈ лікуванні. Лікар зобов'язаний виправдовувати довіру хворого і зберегти в таємниці всі отримані від нього відомості.

Невипадково у Стародавньому Римі медицину образно називали мистецтвом мовчання. Заборону лікарям розголошувати таємницю хворого було зведено в ранг професійного правила, а потім це стало правовою нормою. Обов'язок лікаря зберігати лікарську таємницю прийшов із глибини століть. Так чинили лікарі в усі часи, про що свідчить клятва Гіпократа, 
у якій $є$ такі слова: «Про що 6 я не дізнався під час виконання своїх професійних дій або окрім них, що 6 не побачив і не почув про дії людського життя, які не слід будь-коли розголошувати, я змовчу, уважаючи це таємницею».

У науковій літературі $\epsilon$ чимало публікацій, присвячених лікарській таємниці. у більшості вітчизняних джерел ідеться про проблеми правового регулювання лікарської (медичної) таємниці в законодавстві країни про охорону здоров'я, тоді як зарубіжні науковці акцентують увагу на проблемах збереження конфіденційності особистості пацієнта.

Відомості про стан здоров'я $є$ складовою частиною права на повагу до особистого і приватного життя людини, яке визнано в багатьох міжнародних документах. Так, у ст. 12 Загальної декларації прав людини від 10 грудня 1948 р. зазначено: «Ніхто не може зазнавати безпідставного втручання в його особисте і сімейне життя $<\ldots>\gg$. Міжнародний пакт про громадянські і політичні права від 16 грудня 1966 р. проголошує: «Ніхто не повинен зазнавати свавільного чи незаконного втручання в його особисте і сімейне життя <...>». Конвенція про захист прав людини і основоположних свобод у ст. 8 закріплює: «Кожен має право на повагу до свого приватного і сімейного життя <...>». Про охорону лікарської таємниці також ідеться в Лісабонській декларації стосовно прав пацієнтів 1981 р., у Декларації про політику у сфері забезпечення прав пацієнтів у Європі 1994 р., у Конвенції про захист прав і гідності людини щодо застосування біології та медицини 1997 р., у Європейській хартії прав пацієнта 2002 р. та в Міжнародному кодексі медичної етики 1949 р. тощо.

Про конфіденційність інформації щодо стану здоров'я пацієнта, анонімність його лікування, а також про виняткові випадки розголошення таких відомостей ідеться в таких вітчизняних нормативно-правових актах: у Цивільному кодексі України (ст. 286), Сімейному кодексі України (ст. 30), у законах України «Основи законодавства України про охорону здоров'я» від 1 липня 2014 р. № 1556-VII (ст. 40); «Про інформацію» від 2 жовтня 1992 р. № 2657-XII (ст. 11); «Про протидію поши- ренню хвороб, зумовлених вірусом імунодефіциту людини (ВІЛ), та правовий і соціальний захист людей, які живуть з ВІЛ» (ст. 13) від 12 грудня 1991 р. № 1972XII; «Про психіатричну допомогу» (ст. 6) від 22 лютого № 1489-III (ст. 6); «Про захист населення від інфекційних хвороб» (ст. 26) від 6 квітня 2000 р. № 1645-III; «Про заходи протидії незаконному обігу наркотичних засобів, психотропних речовин і прекурсорів та зловживанню ними» (ст. 14) від 15 лютого 1995 р. № 62/95-ВР; «Про протидію захворюванню на туберкульоз» (ст. 18) від 5 липня 2001 р. № 2586III, а також в Указі Президента України «Про клятву лікаря» від 15 червня 1992 р. № 349 тощо.

Водночас положення окремих вітчизняних нормативно-правових актів містять низку недоліків, які свідчать, що повною мірою законодавчо не забезпечуються належні гарантії проти можливого втручання держави у приватне життя громадян. Зокрема, законодавчо не визначено словосполучення «лікарська таємниця», через що постають труднощі 3 визначенням кола інформації, яка охоплюється лікарською таємницею. Окрім того, спірними $\epsilon$ неоднозначно сформульовані положення окремих нормативно-правових актів, які визначають умови і порядок надання конфіденційної інформації зацікавленим особам. Сумнівною $\epsilon$ правомірність розголошення лікарської таємниці за запитом сторони обвинувачення без рішення суду тощо.

Кінцевою метою встановлення спеціального правового режиму для інформації, що отримується у зв'язку наданням особі медичної допомоги, $\epsilon$ захист прав і законних інтересів пацієнта, створення необхідних умов для ефективного лікування. За відсутності гарантій захисту особа може утримуватися від звернення по необхідне лікування, тим самим наражати своє здоров'я на небезпеку.

Мета статті полягає в аналізі чинної нормативної моделі охорони лікарської таємниці у кримінальному процесі та законодавстві України про охорону здоров'я, визначенні словосполучення «лікарська таємниця», розкритті проблем правового регулювання в даній сфері, вивченні досвіду зарубіжних країн, роз- 
робці науково обґрунтованих пропозицій для вдосконалення чинного законодавства України.

Виклад основного матеріалу. Законодавець не має єдиного підходу до назви досліджуваної категорії і застосовує різну термінологію, коли забезпечує правове регулювання даного виду таємниць. Зокрема, у чинному законодавстві вживаються словосполучення «лікарська таємниця», «конфіденційна інформація», «конфіденційність відомостей», «анонімне лікування», «право на таємницю про стан здоров'я», «таємниця» (ідеться про результати медичного обстеження) тощо. У науковій літературі також трапляється термін «медична таємниця» $[1$, с. $218-219 ; 2$, с. 38 ; 3, с. 43-44; 4$, c. 8$]$.

Розмаїття назв даного виду професійної таємниці зумовлене тим, що за своїм змістом вона $\epsilon$ широким і багатоаспектним явищем. Жоден нормативно-правовий акт не містить вичерпного переліку відомостей, що становлять зміст категорії «лікарська таємниця», оскільки нормативно неможливо охопити всю інформацію, яка не підлягає розголошенню.

Аналіз наукових (I. Петрухін [5, с. 161], Л. Удалова [6, с. 32], Є. Кузьмічова-Кисленко [6, с. 32], I. Дікарєв [7, с. 66], Н. Коробцова [4, с. 9] та інші) і нормативних джерел дає змогу дійти висновку, що цей вид професійної інформації охоплює відомості про: факт звернення по медичну допомогу; анонімність лікування; стан здоров'я; діагноз; історію хвороби; дані про медичне обстеження; мету запропонованих досліджень та лікувальних заходів; прогноз можливого розвитку захворювання; відомості про зараження особи інфекційною хворобою; лікування в закладі з надання психіатричної допомоги; інформацію про людей, які живуть із ВІЛ; відомості про результати тестування особи з метою виявлення ВІЛ; функціональні особливості організму; шкідливі звички; інтимну та сімейну сторони життя громадянина; про родину пацієнта та спосіб життя тощо.

Узагальнюючи викладене, можна констатувати: інформацію, яка охоплюється професійною лікарською таємницею, умовно можна поділити на такі групи, як: відомості про факт звернення по медичну допомогу; дані про сам факт лікування; інформація про стан здоров'я особи; обізнаність із медичним та немедичним характером сімейного й інтимного життя хворого. Останню групу інформації можна отримати як від самого хворого, так і під час надання медичної допомоги в його помешканні, через що вона й набуває особистісного характеру.

Окремі науковці та практики наполягають, що застосування поняття «лікарська таємниця» не $€$ вдалим, його потрібно замінити на термін «медична таємниця», аргументують це тим, що він краще виражає внутрішню сутність конфіденційних відносин особи, яка звернулася по конфіденційну допомогу [2, с. 38], розширює коло суб'єктів збереження конфіденційних відомостей $[3$, с. $45 ; 4$, с. 8] тощо.

На наш погляд, термін «медична таємниця» порівняно зі словосполученням «лікарська таємниця» $\epsilon$ більш вузьким. Він охоплює лише медичну інформацію про особу, водночас залишає поза увагою відомості про факт звернення по медичну допомогу і факт лікування. Невипадково Конституційний Суд України в рішенні від 30 жовтня 1997 р. зазначив, що «лікарська таємниця - це інформація про пацієнта <...>» [8]. Зрештою, словосполучення «лікарська таємниця» $\epsilon$ найпоширенішим у чинному законодавстві (уживається у Кримінальному процесуальному кодексі України (далі - КПК України), Законі України (далі - ЗУ) «Основи законодавства України про охорону здоров'я», Указі Президента України «Про клятву лікаря» тощо).

3 урахуванням вищевикладеного видається, що зміст інформації, яка охоплюється лікарською таємницею, є релевантним.

Дискусійним $€$ питання, чи має лікарська таємниця поширюватися на безпосередньо хворого. У науковій літературі $\epsilon$ різні погляди на те, чи має лікар повідомляти хворому всю інформацію про стан його здоров'я. Адже спокійна, врівноважена, вольова людина, знаючи правду про стан свого здоров'я, буде помічником лікаря, тоді як недовірлива і боягузлива може перешкодити процесу лікування. 
На думку Е. Чеботарьової, розв'язання проблеми, чи повинна особа знати правду про своє здоров'я, пов'язане з вивченням питання про співвідношення чуттєвого і раціонального у психіці хворого, з визначенням, до якого типу - «мислитель» або «художник», за термінологією I. Павлова, - належить людина. Якщо у хворого елементи раціонального підходу придушуються емоціями, то, очевидно, знати йому всю правду про тяжкість захворювання небезпечно [9, с. 79].

3 іншого боку, вагомою була позиція дійсного члена Академії медичних наук СРСР професора А. М'ясникова, який зазначав, що свідома людина має знати правду про стан свого здоров'я, оскільки вона $\epsilon$ не об'єктом лікування, а його природним співучасником.

На наш погляд, в основі рішення лікаря, повідомляти чи ні хворому всю інформацію про стан його здоров'я, має бути єдиний критерій: користь для пацієнта.

Гарантуючи збереження в таємниці відомостей, що охоплюються лікарською таємницею, законодавець створює умови для встановлення конфіденційних відносин між лікарем і пацієнтом, що має велике значення для забезпечення ефективності лікування. Пацієнт не повинен побоюватися, що інформація, яку він довірив лікарю, може стати надбанням громадськості. Проте інтереси пацієнта, який не хоче розголошувати свої особисті таємниці, можуть за значущістю поступатися публічному інтересу, пов'язаному 3 досягненням завдань кримінального провадження, гарантування національної безпеки, захисту економічного добробуту та дотримання прав людини.

Кримінальне процесуальне законодавство України передбачає гарантії охорони лікарської таємниці. Так, відповідно до ч. 2 ст. 65 КПК України, не можуть бути допитані як свідки про відомості, що становлять лікарську таємницю, медичні працівники й інші особи, яким у зв'язку 3 виконанням професійних або службових обов'язків стало відомо про хворобу, медичне обстеження, огляд та їхні результати, інтимну та сімейну сторони життя особи. Згідно із ч. 3 цієї статті, вони можуть бути звільнені від обов'язку зберігати професійну таємницю особою, що довірила їм ці відомості, у визначеному нею обсязі. Такий дозвіл оформлюється в письмовому вигляді й долучається до кримінального провадження.

Отже, відповідно до змісту ст. 65 КПК України лікарська таємниця може мати й абсолютний характер, якщо йдеться про інформацію, що була довірена пацієнтом лікарю про «хворобу, медичне обстеження, огляд та їхні результати, інтимну та сімейну сторони життя особи» під час допиту останнього як свідка.

Ця норма ст. 65 КПК України кореспондується з положеннями Міжнародного кодексу медичної етики (1949р.), у якому зазначено: «Лікар зобов'язаний дотримуватися абсолютної таємниці в усьому, що він знає про свого пацієнта, навіть після смерті».

Лікар $\epsilon$ не єдиним суб'єктом, стосовно якого передбачена пряма заборона допиту як свідка. Це можуть бути й інші особи, яким у зв'язку з виконанням професійних або службових обов'язків стало відомо про відомості, що становлять лікарську таємницю. Однак законодавець у п. 4 4. 2 ст. 65 КПК України не конкретизує коло таких осіб, обмежуючись словосполученням «медичні працівники та інші особи». Застосування термінології зумовлено необхідністю контактування хворого з великою кількістю медичних працівників, вузькою спеціалізацією медиків, наступністю в роботі лікарів тощо.

Обов'язковим $\epsilon$ те, що конфіденційна інформація, яка становить лікарську таємницю, має бути одержана особами «у зв'язку з виконанням професійних або службових обов'язків». Водночас постає питання: чи мають право розголошувати лікарську таємницю лікар та інші особи, яким стала відома така інформація, поза виконанням професійних обов'язків? Зі змісту ст. 65 КПК України випливає, що межі лікарської таємниці не поширюються на відомості, які стали відомі не у зв'язку 3 виконанням професійних функцій. Однак з етичного погляду розголошення будь-якої інформації, що охоплюється словосполученням «лікарська таємниця», $\epsilon$ неприпустимим, оскільки психіка кожної особистості має індивідуальні особливості та ступінь вразливості, може зазнати шкоди. 
Відповідно до змісту ст. 65 КПК України коло осіб, на яких покладено обов'язок зберігати лікарську таємницю, $€$ досить широким, від рядових медиків до посадовців органів управління охорони здоров'я. Так, до суб'єктів збереження лікарської таємниці можна віднести: лікарів, провізорів, фельдшерів, медичних сестер, фармацевтів, молодший медичний персонал (санітари, няньки), осіб, що навчаються (студенти вищих та середніх медичних закладів освіти), немедичний персонал лікувально-профілактичної установи (працівники кадрових, юридичних, фінансових, господарських служб тощо), посадовців органів управління охорони здоров'я (головні лікарі, керівники структурних підрозділів Міністерства тощо).

У КПК Федеративної Республіки Німеччина порівняно із КПК України більш конкретно визначено коло осіб, які не можуть бути допитані як свідки. Зокрема, § 53 КПК ФРН визначає, що право відмови від дачі показань із професійних підстав мають лікарі, зубний лікар, психологи-психотерапевти, дитячий і підлітковий психотерапевти, аптекар і акушерки про те, що їм стало відомо в даній ролі [10].

Вітчизняний законодавець не вважає істотним те, яким шляхом було одержано відомості. Не $\epsilon$ важливим і місце одержання зазначених відомостей, а також спосіб сприйняття цих відомостей (вони можуть бути побачені й почуті) [4, с. 9].

Ст. 65 КПК України не містить жодних обмежень стосовно строків заборони розголошення лікарської таємниці. Це означає, що в разі смерті пацієнта лікар або інші суб'єкти збереження цієї професійної таємниці зобов'язані ї̈ не розголошувати, якщо не має письмового дозволу особи, яка довірила їм ці відомості.

Гарантією дотримання лікарської таємниці $\epsilon$ передбачена ст. 145 Кримінального кодексу України відповідальність за умисне розголошення лікарської таємниці особою, якій вона стала відома у зв'язку з виконанням професійних чи службових обов'язків, якщо таке діяння спричинило тяжкі наслідки.

Зазвичай цілковите збереження лікарської таємниці $€$ неможливим, оскільки це може завдати шкоди суспільству або оточенню хворого. У зв'язку із цим чинне законодавство України передбачає випадки, коли без згоди особи допускається розкриття інформації, що належить до лікарської таємниці.

Проте окремі положення чинного законодавства, які звільняють лікувальні заклади від обов'язку зберігати в таємниці медичні персональні дані, містять неоднакові правові підстави для їх розголошення. Зокрема, ЗУ «Про психіатричну допомогу» містить суперечливу норму про те, що письмового запиту слідчого, прокурора досить для розкриття лікарської таємниці. У ч. 4 ст. 6 цього Закону визначено: «Допускається передача відомостей про стан психічного здоров'я особи та надання їй психіатричної допомоги без згоди особи або без згоди їі законного представника для: (...> 2) провадження досудового розслідування, складання досудової доповіді щодо обвинувачених або судового розгляду за письмовим запитом слідчого, прокурора, суду та представника уповноваженого органу з питань пробації».

Отже, вітчизняний законодавець застосовував відомий за радянських часів підхід, коли за вимогою слідчих і судових органів на керівників закладів охорони здоров'я покладався обов'язок повідомляти відомості про хворобу громадян (ст. 16 Закона «Об утверждении основ законодательства Союза ССР и союзных республик о здравоохранении») [11].

Іншим шляхом вирішується питання про передачу відомостей, що становлять лікарську таємницю, в ЗУ «Про протидію поширенню хвороб, зумовлених вірусом імунодефіциту людини (ВIЛ), та правовий і соціальний захист людей, які живуть із ВІЛ» (ч. 4 ст. 13). Із змісту цього Закону випливає, що запиту слідчого, прокурора буде не досить. Для отримання такої інформації потрібне рішення суду.

Отже, законодавець застосовує різні підходи до визначення підстав для надання стороні обвинувачення відомостей про особу, що становлять лікарську таємницю.

Розголошення лікарської таємниці особою, яка зобов'язана ії зберігати, не кваліфікується як порушення професійного обов'язку і лікарської етики у випадках, коли це передбачено законом. Норми, що визначають умови та порядок надання 
відомостей, які становлять лікарську таємницю, мають бути зрозумілими з метою забезпечення гарантій проти можливого свавілля і зловживань.

Однак в окремих випадках норми закону викладено неоднозначно, вони можуть по-різному тлумачитися зацікавленими особами. Зокрема, у ч. 5 ст. 14 ЗУ «Про заходи протидії незаконному обігу наркотичних засобів, психотропних речовин і прекурсорів та зловживанню ними» зазначено, що відомості про лікування особи в наркологічному закладі можуть бути надані лише правоохоронним органам у разі притягнення цієї особи до кримінальної або адміністративної відповідальності.

Притягнення до кримінальної відповідальності як стадія кримінального провадження починається 3 моменту повідомлення особі про підозру у вчиненні кримінального правопорушення. Виходячи із цього, відомості про лікування особи в наркологічному закладі можуть бути надані лише стосовно особи, яка має статус підозрюваного. Чи повинна така інформація надаватися за запитом правоохоронних органів або лише на підставі ухвали слідчого судді, суду, у законі чітко не визначено.

Окрім того, сторони обвинувачення та захисту повинні мати рівний доступ до такої інформації. Водночас вказівка про те, що відомості про лікування особи в наркологічному закладі можуть бути надані лише правоохоронним органам, призводить до нерівноправності сторін, що $€$ несумісним із принципом змагальності сторін.

Так, гл. 15 КПК України чітко визначає процедуру рівного тимчасового доступу до документів, зокрема й тих, що містять відомості, які становлять професійну таємницю, як для сторони захисту, так і для сторони обвинувачення. Сторони кримінального провадження, відповідно до ст. 160 КПК України, мають право звернутися до слідчого судді під час досудового розслідування чи суду під час судового провадження із клопотанням про тимчасовий доступ до документів, які містять відомості, що становлять лікарську таємницю. Це означає, що фізична або юридична особа, яка має конфіденційну інформацію про приватне життя особи, лише на підставі ухвали слідчого судді або суду зобов'язана надати стороні кримінального провадження можливість ознайомлюватися з відповідними документами, зробити їх копії і за необхідності вилучати їх.

Тому для того, щоб запобігти спірним ситуаціям, пов'язаним із розголошенням конфіденційної інформації або відмовою надання медичними закладами правоохоронним органам інформації, що становить лікарську таємницю, у законах «Про заходи протидії незаконному обігу наркотичних засобів, психотропних речовин і прекурсорів та зловживанню ними» та «Про психіатричну допомогу» має бути передбачено: для лікувального закладу правовою підставою для розкриття відомостей про обставини звернення та лікування особи в закладі охорони здоров'я, а також медичної інформації стосовно неї має бути ухвала слідчого судді або суду.

В окремих випадках на медичні заклади покладається обов'язок за власною ініціативою розголошувати правоохоронним органам відомості, що $€$ лікарською таємницею.

Зокрема, лікувально-профілактичні заклади, до яких доставлено особу внаслідок нещасного випадку (пов'язаною із наявністю тілесних ушкоджень, дорожньо-транспортною пригодою тощо), відповідно до Порядку розслідування та обліку нещасних випадків невиробничого характеру, затвердженого постановою Кабінету Міністрів України від 22 березня 2001 р. № 270, зобов'язані письмово повідомити прокурора й орган досудового розслідування за встановленою формою із зазначенням діагнозу, про обставини, за яких стався інцидент, дату, час травмування та звернення до лікувально-профілактичного закладу, а також іншу інформацію.

Метою такого інформування $€$ повідомлення органів кримінального переслідування про можливий факт учинення злочину. Однак тут $\epsilon$ сумніви в доцільності надання даних про стан здоров'я пацієнта, що становлять професійну лікарську таємницю, без його згоди, а також у разі, якщо пацієнт не хоче розголошувати їх.

Сумнівною також $\epsilon$ доцільність за кожним нещасним випадком надавати інформацію про діагноз та інші відомості, одержані під час медичного обстеження. 
3 одного боку, інтереси пацієнтів за значущістю можуть поступатися інтересам держави у процесі розслідування злочинів. 3 іншого боку, постає питання, чи буде обґрунтованим втручання у право пацієнтів лікувальних закладів на повагу до їхнього приватного життя, якщо вони не мають статусу обвинуваченого, а також якщо в них відсутнє бажання розголошувати відомості, що є предметом лікарської таємниці.

На наш погляд, розголошення такої інформації не узгоджується зі ст. 286 ЦК України, у якій зазначено: «Фізична особа має право на таємницю про стан свого здоров'я, факт звернення за медичною допомогою, діагноз, а також про відомості, одержані при ії медичному обстеженні», а також із правовою позицією Європейського суду з прав людини, який у своїх рішеннях неодноразово підкреслював: особисті дані пацієнта є складовою частиною його приватного життя.

У зв'язку із цим видається доцільним обмежитися лише інформуванням про факт звернення по медичну допомогу без деталізації діагнозу й інших особливостей стану здоров'я. Така інформація має подаватися у знеособленому вигляді, якщо пацієнт не дав добровільної згоди на розголошення даних щодо нього.

Отже, можна зробити такі висновки:

Професійна лікарська таємниця - це наявність відомостей про факт звернення по медичну допомогу; даних про сам факт лікування; про стан здоров'я особи; обізнаність із медичним та немедичним характером сімейного та інтимного життя хворого.

Правовий режим охорони права особи на лікарську таємницю у кримінальному процесі України передбачає можливість його тимчасового обмеження, а в окремих випадках - абсолютну недоторканість цього права.

У п. 4 ч. 2 ст. 65 КПК України обґрунтовано необхідність визначити коло осіб, яких заборонено допитувати як свідків про відомості, які становлять лікарську таємницю;

Ч. 5 ст. 14 закону України «Про заходи протидії незаконному обігу наркотичних засобів, психотропних речовин і прекурсорів та зловживанню ними» потрібно викласти в такій редакції: «Особі, яка добровільно звернулася до наркологічного закладу для проходження курсу лікування, забезпечується, на її прохання, анонімність лікування. Відомості про таке лікування можуть бути надані лише на підставі ухвали слідчого судді або суду».

4. 4 ст. 6 Закону України «Про психіатричну допомогу» варто викласти в такій редакції: «Допускається передача відомостей про стан психічного здоров'я особи та надання їй психіатричної допомоги без згоди особи або без згоди їі законного представника для: 1) організації надання особі, яка страждає на тяжкий психічний розлад, психіатричної допомоги; 2) провадження досудового розслідування, складання досудової доповіді щодо обвинувачених або судового розгляду на підставі ухвали слідчого судді або суду».

\section{ЛITEPATУPA:}

1. Михайлов С. Правова реґламентація медичної таємниці. Вісник Харківського національного університету внтурішніх справ. 2012. № 3 (58). С. 218-226.

2. Ісмаілова У. Поняття, загальна характеристика й ознаки категорії «лікарська таємниця» у законодавстві України. Право і суспільство. 2016. № 4. С. 35-40.

3. Негодченко О. Медична та лікарська таємниці як гаранти інформаційної приватності. Право і суспільство. 2013. № 2. С. 41-48.

4. Коробцова Н. Правове регулювання медичної таємниці. Підприємництво, господарство і право. 2005. № 4. С. 8-11.

5. Петрухин I. Личные тайны (человек и власть). Москва : Изд-во ИГиП РАН, 1998. 232 с.

6. Удалова Л., Кузьмічова-Кисленко $Є$. Лікарська таємниця в кримінальному процесі України : монографія. Київ, 2020. 134 с.

7. Дикарев И. Врачебная тайна в уголовном судопроизводстве. Российская юстиция. 2009. № 4. С. 66-69.

8. Рішення Конституційного Суду України від 30 жовтня 1997 р. № 5-рп. URL: https://zakon.rada.gov.ua/laws/show/v005p710-97\#Text (дата звернення: 14.06.2021). 
9. Чеботарева Э. Врачебная этика. Москва : Медицина, 1970. 99 с. 10. Уголовно-процессуальный кодекс Федеративной Республики Германия Strafprozessordnung (StPO) - научно-практический комментарий и перевод текста Закона. URL: https://publishup.uni-potsdam.de/opus4-ubp/frontdoor/deliver/index/docId/6039/file/ sdrs02.pdf (дата звернення: 01.08.2021).

11. Об утверждении основ законодательства Союза ССР и союзных республик о здравоохранении : Закон СРСР от 19 декабря 1969 г. № 4589-VII. URL: https://docs.cntd.ru/ document/9021016 (дата звернення: 04.08.2021). 